\title{
Socio-Cultural and \\ Linguistic Aspects of Roma Education
}




\title{
Hristo Kyuchukov
}

\author{
Socio-Cultural and \\ Linguistic Aspects of Roma Education
}


Reviewer

Andrzej Radziewicz-Winnicki 


\section{Contents}

Acknowledgments . . . . . . . . . . . . . . . . . . . . . . . . 7

Preface (Jill de Villiers) . . . . . . . . . . . . . . . . . . . . . . . . . . . . . 9

\section{Part one \\ History of Roma education}

Chapter 1.

Roma children and transformative education

Chapter 2.

Good practices in Roma education in Bulgaria during the years of transition .

Chapter 3.

Romani language education in Bulgaria: an overview

Chapter 4.

Roma school mediators

\section{Part two \\ Romani Psycholinguistics}

Chapter 5.

The role of oral traditions in the language development of Roma children

Chapter 6.

The role of Mental State Verbs in the development of Theory of Mind in bilingual Roma children 
Chapter 7.

Acquisition of Romani in a bilingual context

Chapter 8 .

Romani language assessment of Roma children

Chapter 9.

Cultural-ecological theory and the language education of Roma children

Chapter 10.

Bulgarian and Slovak as a second language for Roma children

Chapter 11.

Reading comprehension of Roma and Bulgarian children

Conclusions 145

References 


\section{Acknowledgments}

I would like to thank the anonymous reviewer for his/her suggestions and corrections of the manuscript, as well as the language editor of the book, Yuma Carpenter New, for her great job. Without their help, the book would not have the shape it does.

I would like to thank William New for his comments and suggestion on the earlier version of the book.

Many thanks to Encho Gerganov for his help with the figures in chapter 11.

The book could be of interest to anyone who is interested in Roma, education, and/or cultural studies. It could also serve as a course book for MA and $\mathrm{Ph}$. D. students in the field of education or cultural studies. 


\section{Preface}

The Roma in Europe are again in a state of peril. There is a long history of research by psychologists attempting to prove a genetic basis for purported racial differences in intelligence, namely IQ. It began over a century ago with psychologists newly armed with IQ measures, trying to differentiate those immigrants "fit" for immigration to the United States (Jackson and Weidman, 2004). After the horrors of the Third Reich and racial purification (Gound, 1981), such work fell into disrepute. Ironically, the Civil Rights movement in the United States re-awakened interest in racial differences. Once educational inequalities between Blacks and Whites were acknowledged and began to be redressed, attention turned very quickly to the "achievement gap" in education between the "races" (Jensen, 1973) as if four hundred years of inequality could be solved by desegregating some schools (Onwuegbuzie and Daley, 2001).

One of the leaders of the new interest in racial differences in IQ was Philippe Rushton (see https://psychology.uwo.ca/people/faculty/remembrance/rushton. html). When his work fell into disrepute in American circles, he moved his research base, often without the approval of IRB oversight, to two places where it was not so disfavored: racial differences in South Africa under apartheid, and the Roma in Eastern Europe. For Rushton, the Roma provided a natural experiment: a relatively pure South Asian group living in a European cultural setting.

As recently as Rushton (2007), the Roma were characterized as scoring lower on average than Whites not as a function of disparities in circumstances but because of their ethnicity. Research highlighting low intelligence was used in the past to justify special education, sometimes for even a majority of Roma children (Cvorovic, 2014). Papers within the last ten years (e.g. Bakefr, 2011) make broad generalizations about Roma: that they care little for education and tend to avoid confrontation by withdrawal. In an appalling piece, Bakalar (2004) character- 
izes Roma as following a "strategy" of over-reproduction with little care given to children.

The research in these papers is badly flawed, assuming the "culture-fairness" of Western tests, relying on unsystematic interviews with inadequate control groups, and paying little attention both to the language children were tested in, and to the cultural match between the examiners and the children. Other studies that have taken into consideration the socioeconomic status of the parents, nutritional status, birth weight, and preschool experiences of the children, find the so-called racial gap in IQ between Roma children and others almost inconsequential (Kezdi \& Kertesi, 2011).

The research in the current volume attempts to dispel some myths and to place the development and education of Roma children in their cultural and historical context. The research is conducted with more understanding of the language and cultural milieu in which Roma children grow up. Roma testers present the materials whenever possible, and Romani is used as the language of the test.

"Scientific" reports, especially if they suggest biological causes for population differences, can rapidly become fodder for political extremists, neo-Nazis and racists, whose attacks on Roma in the last decades have not abated (Cvorovic, 2014). There remains a huge gap in the educational experiences of Roma and mainstream children in Europe. Sustained attention and adequate funding is needed to bring justice to their circumstances. That attention must proceed in full acknowledgement of past systemic racist bias, and with a fuller understanding of the cultural and historical context of the Roma.

\section{References}

Bafekr, S. (1999) Schools and their undocumented Polish and "Romany Gypsy" pupils. International Journal of Educational Research, 295-302.

Bakalar, P. (2004) The IQ of Gypsies in Central Europe. The Mankind Quarterly, XLIV, (3\&4), 291-300.

Cvorovic, J. (2014) The Roma: A Balkan Underclass. Ulster: Ulster Institute for Social Research.

Gould, S. J. (1981). The mismeasure of man. New York: Norton.

Jackson, J. P. \& Weidman, N. M. (2004). Race, Racism, and Science: Social Impact and Interaction. ABC-CLIO.

Jensen, A. R. (1973). Educability and Group Differences. London: Methuen.

Kezdi, G. and Kertesi, G. (2011) The Roma/non-Roma test score gap in Hungary. American Economic Review, 101 (3), 519-525. 
Onwuegbuzie, A. J. \& Daley, C. E. (2001), Racial Differences in IQ Revisited: A Synthesis of Nearly a Century of Research. Journal of Black Psychology, 27 (2), 209-220.

Rushton, J. P., Cvorovic, J. \& Bons, T. A. (2007), General mental ability in South Asians: Data from three Roma (Gypsy) communities in Serbia. Intelligence, 35(1), 1-12. 22.

Jill de Villiers

Smith College, MA, USA 
Copy editor and proofreading

Aleksandra Kalaga

Cover design

Tomasz Kipka

The cover page features an excerpt from "La Serrania de La Lindosa, Colombia"

by Susan Roberta Katz

Technical editor

Małgorzata Pleśniar

Typesetting

Bogusław Chruściński

Initiating editor

Paulina Janota

Copyright (c) 2020 by

Wydawnictwo Uniwersytetu Śląskiego

All rights reserved

iD ttps://orcid.org/0000-0002-1965-8908

https://doi.org/10.31261/PN.3998

Kyuchukov, Hristo

ISBN 978-83-226-4021-0

Socio-cultural and linguistic aspects of Roma

(print edition)

education / Hristo Kyuchukov. - Katowice -

ISBN 978-83-226-4022-7

University of Silesia Press, 2020

(digital edition)

Publisher

Wydawnictwo Uniwersytetu Śląskiego

ul. Bankowa 12B, 40-007 Katowice

www.wydawnictwo.us.edu.pl

e-mail:wydawnictwo@us.edu.pl

First impression. Printed sheets: 9.75. Publishing sheets: 10,5. Offset paper grade III, 90g. PN 3998. Price 34.90 PLN (VAT included).

Printing and binding: Volumina.pl Daniel Krzanowski, Księcia Witolda 7-9, 71-063 Szczecin 